\title{
UKEF Development and Importance for Official Export Promotion in the United Kingdom
}

\author{
Agnieszka Dorożyńska, Tomasz Dorożyński*
}

\begin{abstract}
Abstrct: International trade, and export promoting policy in particular, has always been an economic priority for the UK. Official export promoting policy based on a system of financial and insurance mechanisms secures competitiveness of domestic exporters. British export promotion scheme is one among the oldest as it was put into operation in the early 20 th century. In the United Kingdom, the official export promotion scheme is based on a wide range of financial and insurance products offered by the UK Export Finance (UKEF).

The aim of this paper is to assess the activities of the UKEF as an institutional link, which complements the private market by providing assistance to exporters and investors, principally in the form of insurance and guarantees.

To evaluate UKEF activities we used statistical data from UKEF annual reports. Assessment focused on the engagement in promoting export, available financial and insurance instruments as well as sectoral and geographical structure of export covered by the support scheme. Our analysis demonstrates that despite significant drop in exports under official support schemes, there are solid premises in favour of continuing operations of one of the oldest export credit agencies in the world.
\end{abstract}

Keywords: export credits, export finance, official export support

\section{Foreword}

The scheme evolved but its export finance and refinance facility for domestic operators, originally planned to be backed by the government, has not been launched. In fact, it is now delivered by the private sector, meaning no institution of eximbank type that would perform these functions with government support has been established. The fact that the state did not interfere with export credit financing and refinancing did not hamper the development of the scheme. That was due to a large extent to the well developed financial market and the involvement of commercial banks in export support.

In the United Kingdom the government supports exporters and commercial banks through the official export credit agency UKEF/ECGD. Since 10 November 2011 it has the operational name of UK Export Finance (UKEF). The name, Export Credits Guarantee Department (ECGD), continues to be used for all official documents. The paper assesses the activities of the UKEF as an institutional link, which complements the private market

\footnotetext{
* dr Agnieszka Dorożyńska, Katedra Międzynarodowych Stosunków Gospodarczych, Uniwersytet Łódzki, e-mail: adorozynska@uni.lodz.pl; dr Tomasz Dorozyński, Katedra Wymiany Międzynarodowej, Uniwersytet Łódzki, e-mail: tdorozynski@uni.lodz.pl.
} 
by providing assistance to exporters and investors, principally in the form of insurance and guarantees.

\section{Agency organisation}

UKEF/ECGD Export Credit Guarantee Department (ECGD) is the agency responsible for export support and promotion. It was established in 1919 to support exports to Russia and to help the British industry to recover after World War I. Although the nature of assistance and products has changed over the years of the agency's operations, its main function consisting in providing exporters (or financial institutions that support exporters) with insurance and guarantees against the risk of not being paid by overseas buyers has remained unchanged (ECGD, 2004, p. 5). Since 1919 the agency supports British exporters and since 1972 also British foreign investors. ECGD operations in the field of short-term export credits were privatised in December 1991, thus ECGD offers insurance that covers medium- and long-term export credits and capital goods purchased for foreign investment projects in non-OECD countries (Mah, 2003, pp. 1-2).

Privatisation decision was taken for the following reasons (ECGD Report, 2000, p. 21):

- formal changes in the European Community vis-a-vis short-term insurance provided by insurance companies,

- recognition that the private sector is capable to insure and reinsure commercial and political risks involved in export transactions,

- profitability of operations that involved short-term export credits.

The UKEF mission is to assist British exporters of goods and services as well as British investors abroad to successfully face overseas competitors and ensure benefits to the British economy. Having the above mentioned goals in mind, the agency provides:

- trade credit insurance to exporters against the risks of non-payment for amounts owed under export contracts,

- guarantees to banks to support working capital financing and raising of contract bonds on behalf of exporters,

- guarantees to banks and investors in the debt capital markets in respect of medium/long term loans to overseas buyers who purchase goods and services from UK exporters,

- direct lending to overseas buyers who purchase goods and services from UK Exporters,

- political risk insurance for investments made overseas.

On top of that, in order to accomplish its statutory tasks it pays special attention to:

- more openness and transparency in UKEF operations,

- expanded competence and more prominent role of the Export Guarantees Advisory Council (EGAC),

- better orientation at the needs of small and medium-sized exporters and investors, 
- ensuring the compliance of UKEF policy and operations with government goals related to the promotion of sustainable development, protection of human rights, and market competition rules.

Operations of the British agency are regulated by The Export and Investment Guarantees Act (EIGA) adopted in 1991.

UKEF is a government department that reports to the Secretary of State for Business, Innovation and Skills. By virtue of the Act of 1991 HM Treasury is expected to approve all guarantees issued by the Agency. However, in practice decisions with respect to the majority of transactions are taken independently by the UKEF. Only controversial transactions are consulted first with HM Treasury and with other ministerial departments. In such cases also The Export Guarantee Advisory Council acts in its advisory capacity.

\section{UKEF financial and insurance instruments}

Until 1 December 1991 UKEF offered insurance of short-term export credits. As we have mentioned above, these operations were privatised meaning short-term export credit insurance was excluded from the UKEF portfolio to be provided exclusively by the private sector until 2011. Following the financial crisis of 2007-2008 UKEF had to rebuild its support for short-term business.

UKEF instruments can be divided into financial and insurance facilities.

\section{Table 1}

UKEF's product range

\begin{tabular}{|c|c|c|c|c|c|c|c|c|c|c|c|c|}
\hline & \multicolumn{10}{|c|}{ Products } & \multicolumn{2}{|c|}{$\begin{array}{l}\text { Score } \\
\text { (out of 10) }\end{array}$} \\
\hline & $\begin{array}{l}\text { short } \\
\text { term } \\
\text { insu- } \\
\text { rance }\end{array}$ & $\begin{array}{l}\text { export } \\
\text { credit } \\
\text { sche- } \\
\text { mes }\end{array}$ & $\begin{array}{l}\text { fixed } \\
\text { rate fi- } \\
\text { nancing } \\
\text { (CIRR) }\end{array}$ & $\begin{array}{l}\text { foreign } \\
\text { exchan- } \\
\text { ge risk } \\
\text { cover }\end{array}$ & $\begin{array}{l}\text { direct } \\
\text { len- } \\
\text { ding }\end{array}$ & $\begin{array}{l}\text { instru- } \\
\text { ment } \\
\text { insu- } \\
\text { rance }\end{array}$ & $\begin{array}{l}\text { bond } \\
\text { support } \\
\text { scheme }\end{array}$ & $\begin{array}{l}\text { unfair } \\
\text { calling } \\
\text { insu- } \\
\text { rance }\end{array}$ & $\begin{array}{l}\text { letter of } \\
\text { credit } \\
\text { guar- } \\
\text { antee } \\
\text { scheme }\end{array}$ & $\begin{array}{l}\text { wor- } \\
\text { king } \\
\text { capital } \\
\text { facillity }\end{array}$ & UKEF & $\begin{array}{l}\text { all } \\
\text { ECA's } \\
\text { average }\end{array}$ \\
\hline 2010 & No & Yes & Yes & No & No & Yes & No & Yes & Yes & No & 5 & 7.11 \\
\hline 2011 & Yes & Yes & No & No & No & Yes & Yes & Yes & Yes & Yes & 7 & 7.28 \\
\hline 2012 & Yes & Yes & No & No & No & Yes & Yes & Yes & Yes & Yes & 7 & 7.69 \\
\hline 2013 & Yes & Yes & No & No & Yes & Yes & Yes & Yes & Yes & Yes & 8 & 7.42 \\
\hline
\end{tabular}

Source: UK Export Finance Supporting the National Export Challenge, BExA (2013, p. 4).

In 2013 the number of products available from UKEF increased to 8 out of 10. Two key products are not offered by UKEF: a fixed interest rate mechanism (offered by the majority of competitor country ECAs), although this instrument was available until 2010, and tender to contract foreign exchange risk cover. It is worth noting that UKEF average score in 2013 was higher than the average score for all ECAs. 
Available schemes, together with requirements and benefits to exporters or banks, are presented in Table 2.

The highest support goes to buyer and supplier credit financing (91\%). The remaining products are used to a clearly smaller degree (Figure 1).

\section{Table 2}

Financial-insurance instruments offered by UKEF in 2016

\begin{tabular}{|c|c|c|}
\hline Instrument type and characteristics & \multicolumn{2}{|l|}{ Description } \\
\hline 1 & \multicolumn{2}{|l|}{2} \\
\hline 1. Credit insurance: & \multicolumn{2}{|c|}{$\begin{array}{l}\text { insures against the commercial and political risks of not being paid under } \\
\text { an export contract. }\end{array}$} \\
\hline a) Export insurance policy & $\begin{array}{l}\text { Requirements: } \\
\text { - exporter's business based in the UK } \\
\text { - buyer's business based outside of } \\
\text { the UK } \\
\text { - contract exceeding } 2 \text { years } \\
\text { - documented exporter's failure to } \\
\text { acquire guarantee in the commer- } \\
\text { cial market }\end{array}$ & $\begin{array}{l}\text { Benefits: } \\
\text { - up to } 95 \% \text { cover is provided to } \\
\text { the exporter } \\
\text { - the exporter is covered against } \\
\text { loss suffered due to specified } \\
\text { risks }\end{array}$ \\
\hline b) Bond insurance policy & $\begin{array}{l}\text { Requirements: } \\
\text { - exporter's business based in the UK } \\
\text { - buyer's business based outside of } \\
\text { the UK } \\
\text { - the bond must not be a tender or bid } \\
\text { bond or a bond given for contract } \\
\text { payments that are aid funded by the } \\
\text { UK government }\end{array}$ & $\begin{array}{l}\text { Benefits: } \\
\text { - the exporter is given up to } \\
100 \% \text { cover } \\
\text { - the exporter is protected against } \\
\text { loss suffered because of unfair } \\
\text { calls by the buyer on the bond } \\
\text { or by the local bank on the } \\
\text { counter-guarantee } \\
\text { - the exporter is protected against } \\
\text { fair calls caused by certain } \\
\text { political events }\end{array}$ \\
\hline 2. Overseas investment insurance & \multicolumn{2}{|c|}{$\begin{array}{l}\text { An overseas investment insurance policy covers the risk of loss resulting } \\
\text { from certain political events in connection with an investment made by an } \\
\text { investor in the United Kingdom in an enterprise outside the UK. }\end{array}$} \\
\hline $\begin{array}{l}\text { Requirements: } \\
\text { - the investor must be carrying on } \\
\text { business in the United Kingdom } \\
\text { and not simply acting as a con- } \\
\text { duit for investment from outside } \\
\text { the United Kingdom } \\
\text { - the investment must be made in } \\
\text { an enterprise outside the United } \\
\text { Kingdom } \\
\text { - where cover is requested for } \\
\text { a guarantee given in respect of } \\
\text { an investment in an enterprise, } \\
\text { the person giving the guarantee } \\
\text { must have an interest in that } \\
\text { enterprise }\end{array}$ & \multicolumn{2}{|c|}{$\begin{array}{l}\text { Benefits: } \\
\text { - any investment of resources may be considered for cover, including } \\
\text { loans or subscriptions for shares } \\
\text { - indirect investments and guarantees given to other investors may also be } \\
\text { covered up to } 90 \% \text { of losses can be covered resulting from the specified } \\
\text { events } \\
\text { - the policy may be renewed annually on the same terms and premium } \\
\text { rate and run for up to } 15 \text { years } \\
\text { - on each renewal the investor can adjust the amount of cover to reflect } \\
\text { the amount of its investment in that year provided that it does not exceed } \\
\text { a specified maximum insured amount }\end{array}$} \\
\hline
\end{tabular}




\begin{tabular}{|c|c|c|}
\hline 1 & \multicolumn{2}{|l|}{2} \\
\hline $\begin{array}{l}\text { 3. Loans or loan guarantees } \\
\text { to banks }\end{array}$ & \multicolumn{2}{|c|}{$\begin{array}{l}\text { Medium and long-term loans to finance UK export contracts. It is also po- } \\
\text { ssible to deliver direct lending in partnership with a private sector provider }\end{array}$} \\
\hline a) Direct lending & Requirements: & Benefits: \\
\hline & $\begin{array}{l}\text { - exporter's business based in the UK } \\
\text { - The maximum amount of the loan } \\
\text { is } 85 \% \text { of the contract value. A mi- } \\
\text { nimum of } 15 \% \text { of the contract value } \\
\text { must be paid directly to the exporter } \\
\text { by the buyer before the loan starts } \\
\text { to be repaid } \\
\text { - repayment period is at least } 2 \text { years } \\
\text { and interest will be at a fixed rate } \\
\text { - CIRR }\end{array}$ & $\begin{array}{l}\text { - the exporter is paid as though it } \\
\text { has a cash contract } \\
\text { - the buyer or borrower has time } \\
\text { to pay over a number of years } \\
\text { and can borrow at a very com- } \\
\text { petitive fixed rate of interest }\end{array}$ \\
\hline
\end{tabular}

\section{b) a buyer credit}

This is a guarantee to a bank that makes a loan to an overseas buyer. The purchase of capital goods and/or services worth at least $£ 5$ million (in the main trading currencies)

\section{Requirements:}

- exporter's business based in the UK

- the maximum amount of the loan is $85 \%$ of the contract value

- a minimum of $15 \%$ of the contract value must be paid directly to the exporter by the buyer before the loan starts to be repaid

- repayment period is at least 2 years

\section{Benefits:}

- the exporter is paid as though it has a cash contract

- the buyer or borrower has time to pay over a number of years and can borrow at fixed or floating rates

- the lending bank receives a guarantee for full repayment of the loan plus interest

- the exporter is paid as soon as the goods have been shipped and/or services performed

- the buyer or borrower has time to pay over a number of years and can borrow at fixed or floating rates

- the bank receives a guarantee for the amounts due under the bills of exchange, promissory notes or the loan

Source: Author's study based on information available on the website www.gov.uk.



Figure 1. UKEF support to exporters under various schemes in 2014/2015

Source: Corporate report UK Export Finance Performance Highlights: 2014 to 2015, www.uk.gov. 
Nevertheless, we need to bear in mind that considering the number of companies supported with the above-mentioned products, more than half of them (58\%) used bond support or export working capital, $1 / 3$ of companies benefited from export or bond insurance $(29 \%)$, which is shown in the Figure 2.

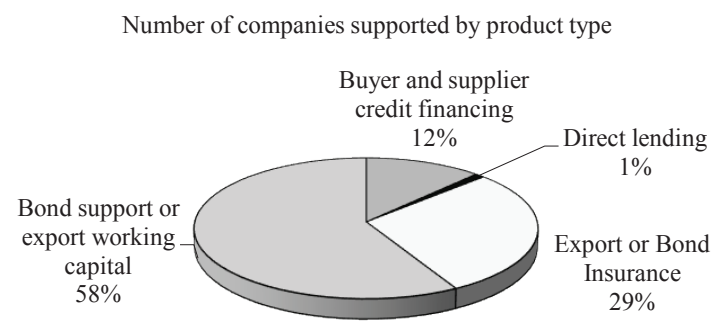

Figure 2. Per cent of companies that benefited from products available in UKEF in 2014/2015

Source: Corporate report UK Export Finance Performance Highlights: 2014 to 2015, www.uk.gov.

The analysis of export credit agency operations in the United Kingdom after World War II shows that the highest degree of UKEF support was provided in the mid-1970s when insurance covered almost $35 \%$ of British exports while in other countries only ca. $10 \%$ export transactions were insured. At that time, UKEF was the biggest insurance company in the world (Lipińska 1975).

In the early 1950 s the share of exports covered with UKEF insurance was gradually increasing (from $11.5 \%$ in $1949 / 50$ to $18.3 \%$ in 1959/60). Subsequent years brought further increases and in the late 1960s the share of exports covered with insurance exceeded $30 \%$. The biggest engagement in insuring British exports, as we have already stated, was reported in the mid-1970s.

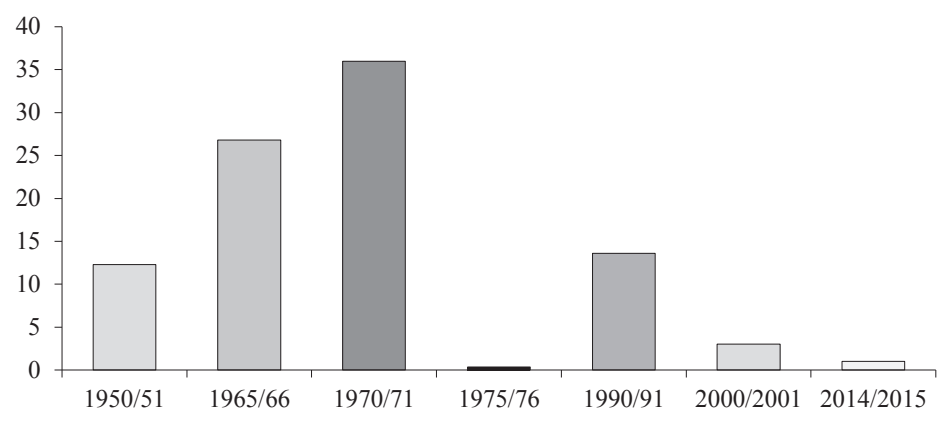

Figure 3. Share of insured export in total British exports in 1950-2015 (\%)

Source: Olszewski (1974) p. 250 and own calculations based on NERA and Annual Reports UKEF/ECGD (1995-2015). 
Since the 1990s we can observe decreasing share of exports covered with insurance scheme, which is consistent with the tendency revealed among other leading export credit agencies. Until the mid-1990s the share dropped to $2.6 \%$ and in 2015 it was about $1 \%$.

Results reported by UKEF until the mid-1970s demonstrate vital role of the agency for the British economy and its input into the growth of exports. In 2012 UKEF generated £211 of export orders for each $£ 1$ of operating costs, a near doubling, and at no cost to UK taxpayers.

Substantial involvement of UKEF and effective support to export can be attributed to:

- very well developed money and capital market in the United Kingdom,

- years of vast experience in trade, insurance and financing transactions in international trade,

- variety of insurance and guarantee products (e.g. guarantees for services, market research, production-related risk, special guarantees, etc.),

- extension of agency operations by opening up the possibility to offer guarantees for the period between 3 and 5 years (in 1952) and covering all countries, with which British exporters entered into commercial transactions with UKEF schemes,

- adjusting the terms of insurance protection to the requirements of competitive market and to clients' needs, e.g., insurance for buyers' credits denominated in local currency and meeting convertibility requirement,

- preferential interest rate for credits guaranteed by the UK government,

- full $(100 \%)$ insurance cover for some export credits (for medium- and long-term credits with constant interest rate), to compare, Coface, Hermes, CESCE and other European ECAs provide up to $95 \%$ cover to the banks (Drummond, 2008),

- taking over refinancing of medium and long-term credits (until then export credits with the repayment period of over 2 years could also be refinanced by the Bank of England),

- low insurance premiums charged by UKEF decisive for competitiveness of British exports.

Drop in exports executed within the support scheme that we can see in Figure 3 was largely due to the debt crisis in developing countries and limited possibilities to use subsidies as a result of limitations imposed on official support to export offered by ECAs in accordance with the OECD Agreement.

\section{Sector and geographical structure of UKEF operations}

For several years already the civil sector (energy, construction, telecommunications, mining, petrochemical) and aerospace industry interchangeably lead in the ranking of the highest insurance cover provided by UKEF. Almost $90 \%$ of all insurance cover is addressed to them. The remaining share goes to the transactions from the defence sector (Tab. 3). 
Table 3

Sector structure of UKEF insurance in 1999/2000-2014/2015 (\%)

\begin{tabular}{lllllll}
\cline { 2 - 6 } & $2014 / 2015$ & $2013 / 2014$ & $2012 / 2013$ & $2011 / 2012$ & $2010 / 2011$ & $1999 / 2000$ \\
\hline Aerospace & 35 & 42 & 43 & 79 & 62 & 4 \\
Civil sector & 60 & 58 & 10 & 21 & 34 & 47 \\
Defence sector & 5 & $<1$ & 47 & $<1$ & 4 & 29 \\
\hline
\end{tabular}

Source: own studies based on Annual Reports UKEF (2014/2015).

The share of premium collected per region suggests that UKEF insurance and guarantee portfolio is dominated with transactions with Middle East, African and Asian countries, which illustrates Figure 4.



Figure 4. Geographical structure of insured export based on premiums collected in 2013-2015

Source: own studies based on Annual Reports UKEF (2013/2014-2014/2015).

Nowadays, over $80 \%$ of UKEF business related to the taking over of risk focuses on the markets of Middle East, Africa, and Asia. For some years the list of the main markets includes: Algeria, Azerbaijan, Brazil, China, Colombia, Egypt, Ethiopia, France, Kenya, Mexico, Morocco, Oman, Panama, Philippines, Saudi Arabia, Singapore, South Africa, Spain, Tanzania, Tunisia, Turkey, Uganda, USA, and Vietnam. In 2014/2015 Asian countries recorded an increase of 11 percentage points. Increase in global demand and intra-regional trade, increasingly more based on trade with China, helped boost growth in the region.

\section{Assessment of UKEF}

The above presented analysis indicates that the share of export supported by UKEF is decreasing. Moreover, companies interested in getting UKEF support have identified some weaker points in the agency, such as (ECGD, 2004, pp. 10-12): 
- insurance premiums or guarantee fees much above the minimum rates decided by the OECD or charged by other export credit agencies,

- prolonged time of waiting for the approval of a particular transaction for insurance,

- low propensity to introduce innovative products, unlike other agencies that compete with it.

In the light of the above, UKEF appears to be lagging behind by operating to lower standards than some of its main OECD competitors (e.g. Canada's ECA, the EDC, Germany's ECA, Euler Hermes) (Amnesty International UK, 2013, p. 18). It is also hard to unambiguously conclude that UKEF is more effective in providing insurance and guarantee cover than private sector operators as the public sector does not compete on equal footing with the private sector. Such assessment could be made if we successfully eliminated subsidies. On the other hand, elimination of financial or guarantee support to export credits would increase the cost of financing exports of capital goods by British exporters. Hence doubts with respect to the rationale of government interference in export promotion by UKEF.

An argument for UKEF official support to exporters is that the Agency does not operate under conditions of perfect competition hence the need to eliminate market distortions (NERA, 2003, pp. 40-41). The latter concern, inter alia, rules of origin that apply to exported goods. Adequate amount of domestic content is the condition for covering them with insurance. It reduces competition between export credit agencies. UKEF must provide evidence that exported goods have $20 \%$ domestic content to qualify them for insurance. Other competing agencies have similar rules (20-30\%) but there are some, which do not require the condition to be met (Tab. 4).

\section{Table 4}

Comparison of content policies of some ECAs, 2014

\begin{tabular}{llllll}
\cline { 2 - 5 } & $\begin{array}{l}\text { EXIM } \\
\text { (USA) }\end{array}$ & $\begin{array}{l}\text { EDC } \\
\text { (Canada) }\end{array}$ & $\begin{array}{l}\text { Coface } \\
\text { (France) }\end{array}$ & $\begin{array}{l}\text { Hermes } \\
\text { (Germany) }\end{array}$ & $\begin{array}{l}\text { UKEF } \\
\text { (United } \\
\text { Kingdom) }\end{array}$ \\
\hline $\begin{array}{c}\text { Is there a requirement to ship foreign } \\
\text { content from ECA's country? }\end{array}$ & YES & NO & NO & NO & NO \\
$\begin{array}{c}\text { Will the cover automatically be reduced } \\
\text { if foreign content exceeds } 15 \% ?\end{array}$ & YES & NO & NO & NO & NO \\
$\begin{array}{c}\text { Is there a minimum amount of domestic } \\
\text { content required to qualify for cover? }\end{array}$ & NO & NO & YES (20\%) & YES (30-70\%) & YES (20\%) \\
$\begin{array}{c}\text { When local cost support is maximized } \\
\text { at } 30 \% \text {, is the amount of eligible } \\
\text { foreign content decreased? }\end{array}$ & NO & NO & YES & YES & NO \\
\hline
\end{tabular}

Source: Export-Import Bank of The United States Report to the U.S. Congress on Global Export Credit Competition, EX-IM Bank (2015) p. 76. 
Market failure is a standard argument that justifies providing export credit insurance and guarantees by the British UKEF. Other arguments include:

- possibility to carry and control higher risk, especially for medium and long-term transactions for supplies of capital goods and to act as an insurer of the last resort,

- UKEF access to unofficial information ${ }^{1}$ as the agency is better placed to estimate risk and prevent losses. Besides, the government has got specific instruments that reduce the risk of loss and enable the recovery of damages paid if losses arise,

- insurance and guarantee products offered by UKEF, an institution backed by the government and not threatened with insolvency are more credible and trustful to banks,

- subsidies help accomplish goals oriented at assisting the poorest countries,

- providing level playing field as other governments also support their exporters.

\section{Conclusions}

UKEF is one of the world top export credit agencies. It delivers its mission that consists in supporting domestic exporters and, predominantly, in securing for them a level playing field in international markets by offering a wide range of financial and insurance instruments. The above-presented analysis of its operations indicates that the agency attempts to react to its clients' needs by expanding its product range. We need to stress its significant input into the growth of export confirmed by data from 2012 when UKEF generated $£ 211$ of export orders for each $£ 1$ of operating costs, a near doubling.

\section{References}

Amnesty International UK (2013). A History of Neglect UK Export Finance and Human Rights.

Corporate report UK Export Finance Performance Highlights: 2014 to 2015. Retrieved from: www.uk.gov.

Drummond, R. (2008). The Role of Export Credit Agencies in Project Financing. Project Finance. Retrieved from: http://whoswholegal.com/news/features/article/11811/the-role-export-credit-agencies-project-financing.

ECGD (2000). Reinsurance for Exports Sold on Short Terms of Credit, Annex A. In: A Report on the Provision of ECGD reinsurance for Export Sold on Short terms of Payment. ECGD July.

ECGD (2004). The Work of The Export Credit Guarantee Department. Sixth Report of Session 2003-2004. House of Commons Trade and Industry Committee.

Estimating The Economic Costs and Benefits of ECGD. A Report for The ECGD (2003). NERA.

Lipińska, A. (1975). Kredyty eksportowe w krajach kapitalistycznych. Systemy, mechanizmy, koszty. Warszawa: PWE.

Mah, J.S. (2003). The Export Insurance System and Export Supply of Britain. University of Connecticut, Department of Economics Working Paper Series.

NERA and Annual Reports UKEF/ECGD (1995-2015).

Olszewski, A. (1974). Ubezpieczenie kredytów eksportowych na tle zasad kredytowania i finansowania transakcji eksportowych. Warszawa.

UKEF (2013). UK Export Finance Supporting the National Export Challenge. BExA.

\footnotetext{
${ }^{1}$ ECGD has got access to non-published information on the agency and social and economic situation of other countries, e.g., from bilateral meetings of the British government or diplomatic cooperation. Such information helps estimate political risk, especially important for medium and long-term transactions.
} 


\section{ROZWÓJ I ZNACZENIE UKEF W ZAKRESIE OFICJALNEGO WSPIERANIA EKSPORTU W WIELKIEJ BRYTANII}

Streszczenie: Handel międzynarodowy, a zwłaszcza polityka proeksportowa, zawsze był priorytetem dla gospodarki Wielkiej Brytanii. Realizacja polityki oficjalnego wspierania eksportu w oparciu o system składający się z mechanizmów finansowych i ubezpieczeniowych, zapewniała konkurencyjną pozycję krajowym eksporterom. Angielski system wspierania eksportu jest jednym z najdłużej funkcjonujących, bowiem początek jego rozwoju przypada na wczesne lata XX wieku. Celem artykułu jest ocena działalności UKEF jako instytucjonalnego ogniwa, które udziela wsparcia eksporterom i inwestorom, uzupełniając w ten sposób ubezpieczeniowo-gwarancyjną ofertę rynku komenrcyjnego.

Do oceny funkcjonowania UKEF wykorzystano dane statystyczne z raportów rocznych agencji UKEF. Ocenie poddano stopnień zaangażowania we wspieranie krajowego eksportu, dostępne instrumentarium finansowo-ubezpieczeniowe oraz strukturę branżową i geograficzną wspieranego eksportu. Z przeprowadzonej analizy wynika, iż mimo znacznego spadku eksportu objętego oficjalnym wsparciem, istnieją przesłanki dla kontynuowania działaności jednej z najstarszych agencji kredytów eksportowych na świecie.

\section{Cytowanie}

Dorożyńska, A., Dorożyński, T. (2016). UKEF Development and Importance for Official Export Promotion in the United Kingdom. Finanse, Rynki Finansowe, Ubezpieczenia, 3 (81), 57-67. DOI: 10.18276/frfu.2016.81-06. 